\title{
A Paperless Engineering Technology First-Year Seminar Course Emphasizing Critical Thinking, Communication, and Teamwork
}

\author{
Scott Segalewitz \\ University of Dayton
}

\begin{abstract}
The engineering technology first-year seminar provides students with an effective introduction to engineering technology principles and practices. Facilitated by the department chair, University of Dayton Engineering Technology students experience tools necessary for success in a technical curriculum. The course is essentially paperles s, taking advantage of currently available Web technology while reinforcing the University's mission of "connected learning." The course outcomes align to meet many of the department's goals including developing scholarship and critical thinking skills, leadership and team building; problem solving and decision-making, professional ethics, and communication skills. This one-credit hour course contains exercises and discussion in professional ethics and integrity, goal setting, effective learning, early career development, networking, University policies and procedures, and an introduction to engineering technology disciplines. By keeping the class size relatively small, these tools are presented in a collaborative manner that facilitates active learning and stresses critical thinking, teamwork, and effective communication. Requirements for homework assignments, which vary between individual work and group collaboration, are posted on the course Web site, and all assignments are submitted electronically. Overall, students report a high degree of satisfaction with this course. They welcome the interaction with their peers, and appreciate the flexibility afforded them through electronic communication.
\end{abstract}

\section{Introduction}

It is common knowledge that a strong technical curriculum is required to produce graduates who are ready to enter the workforce. However, success in college hinges on the student's ability to excel in a new learning environment where the focus of their educational experience is on discovery and active learning. This is further complicated by the fact that for many first-year students, university life represents their first prolonged experience being in control of their own education and environment. This new environment can present an insurmountable challenge for first-year students. Nationally, approximately $30 \%$ of college students do not survive their first year ${ }^{1}$.

The University of Dayton Department of Engineering Technology currently has four programs accredited by the Technology Accreditation Commissions of the Accreditation Board for Engineering and Technology (TAC of ABET), and a relatively new program in 
Computer Engineering technology is scheduled to undergo it's initial accreditation review

during the next departmental visit. Students pursuing a degree in engineering technology at the University of Dayton have the option of entering the Department of Engineering Technology enrolled in one of the five majors: Computer (CET); Electronic (EET), Industrial (IET), Manufacturing (MFG); or Mechanical (MCT). During their first semester, they begin taking a cadre of classes leading to graduation in their area of interest. A growing number of students, however, know they want to pursue a technical career, but are undecided about which direction to follow. These students enroll in Undeclared Engineering Technology (UET), allowing them to take classes in a variety of disciplines within the department. This growing population needs to be exposed to all of the possible career paths available in order to make an educated decision about their future.

To increase student retention in the Department of Engineering Technology, and to give students a better sense of the field, faculty developed the Engineering Technology First Year Seminar in the late $1950 \mathrm{~s}^{2}$. All Engineering Technology students enroll in the course during their first semester at the University. Since it's inception, the course has continued to evolve taking into account the current tools and new educational paradigms. Initial tools included use of the slide-rule, whereas today's student is computer savvy and has grown to expect electronic communication and multimedia-enhanced content. Initial delivery was focused in the classroom with the instructor and the textbook as the primary sources of information. Current technology, however, eliminates the location boundaries and the limited extent of classroom material, and brings worldwide resources to the student. Students can now, more than ever, be exposed to a practically limitless breadth of resources and information.

\section{The Learning Environment}

As the University of Dayton Engineering Technology First-Year Seminar continued to evolve, it was decided that the number of students in a section would be kept small to facilitate discussion and team projects. Depending on annual enrollment, multiple sections are available with each now limited to approximately 25 students. Although some traditional "lecture" material is presented throughout the course, the majority of the learning is accomplished through group discussion and individual discovery facilitated by a subject matter expert (SME). SMEs include personnel from the Career Services Center, the Learning-Teaching Center, the Marianist Family, or University engineering technology programs.

The University's computer requirement puts all students on the same technological level, and since all buildings, including student housing, are connected to a high-speed fiber optic network, information access is commonplace throughout the University. Three years ago, The University of Dayton established the current communications standard, which utilizes the Lotus suite of communication tools. This includes Lotus Notes for e-mail and time management; Lotus QuickPlace for threaded discussions and document sharing; Lotus SameTime for real-time collaboration; and Lotus LearningSpace for course management. 
The mainstreaming of technology into the University has transformed the method of distributing course content from synchronous to asynchronous - anytime, anywhere delivery. The learning environment now extends seamlessly beyond the classroom into any environment connected by current technology. Because students are accessing course material from locations beyond the classroom, paperless exchange of information is necessary.

Currently, all course materials including lecture notes, tutorials, exercises, assessments, and the like, are available via the course LearningSpace. Students collaborate outside of class either by e-mail, synchronous chat, or traditional face-to-face interaction. All assignments are submitted by e-mail to the instructor.

\section{Content Development}

Like all courses within the Department of Engineering Technology, continuous quality improvement necessitates that changes in delivery methods occur simultaneously with modification of course content. All programs within the department demonstrate plans for continuous quality improvement (CQI), in concert with TAC of ABET Engineering Technology Criteria 2000 (ET2K) ${ }^{3}$. Therefore, demonstration of CQI principles, as they relate to the department, is apparent. The First-Year Seminar course goals relate to the department's goals, and consequently to the TAC of ABET a-k criteria, as demonstrated in Table 1.

By incorporating current technology and electronic communication into the course, students are further prepared to demonstrate "an appropriate mastery of the...modern tools of their disciplines" (Criterion 1a), and "competence in computer applications appropriate to the discipline" (Criterion 2). Furthermore, since distance learning courses are rapidly becoming commonplace in higher education, students will be prepared with the necessary tools to participate in lifelong learning (UD ET Goal 9, ET2K Criterion 1h). 
Table 1. Relating FYS Course Goals to the Department and ET2K Criteria.

\section{Course Goal}

1. Encourage awareness of academic integrity \& professional ethics.

\section{Department Goal}

8. Promote awareness of professional ethics, social impacts, and contemporary practice issues.

2. Develop critical thinking \& communication skills.
2. Provide an environment conducive to scholarship \& critical thinking.

\section{ET2K Criterion}

1i. an ability to understand professional, ethical, and social responsibilities

\section{Provide opportunity to} develop communication and interpersonal skills.

\begin{tabular}{lll}
$\begin{array}{l}\text { 3. Promote learning } \\
\text { through working in } \\
\text { groups and teams. }\end{array}$ & $\begin{array}{l}\text { 3. Provide opportunities for } \\
\text { leadership and team- } \\
\text { building skills. }\end{array}$ & $\begin{array}{c}\text { 1e.an ability to function } \\
\text { effectively on teams }\end{array}$ \\
\hline
\end{tabular}

4. Develop an appreciation

of early career preparation \& networking.

5. Investigate educational expectations \& careers in engineering technology.

6. Promote an understanding of university policies, procedures, and culture.

NOTE: The numbers for each goal, as defined by the Department of Engineering Technology, are included to facilitate their reference elsewhere in the text of this document. 


\section{Course Content}

The First-Year Seminar course content is roughly divided into five areas deemed necessary by the faculty to support student success in the engineering technology curriculum, and beyond. The course consists of discussion and exercises in each of these areas including: ethics; academic expectations and skills; career preparation; University policies, procedures, and culture; and the engineering technology field. The following tables show the discussion topics and exercises as they relate to the categories for success and the overall course goals.

Table 2. Discussion Topics and Exercises Related to Ethics

\begin{tabular}{lcc}
\hline Discussion Topics \& Exercises & \multicolumn{2}{c}{$\begin{array}{c}\text { Course } \\
\text { Goal }\end{array}$} \\
\hline $\begin{array}{l}\text { Academic Integrity. Locate and summarize the University's policy } \\
\text { on academic integrity. }\end{array}$ & A1 & 1 \\
\hline $\begin{array}{l}\text { Professional Ethics \& Integrity. Given an engineering situation } \\
\text { where a question of ethics was concerned, discuss the issues and } \\
\text { possible outcomes. }\end{array}$ & D & 1,2 \\
\hline $\begin{array}{l}\text { Code of Ethics. Investigate codes of ethics for various professional } \\
\text { organizations; develop a "Code of Ethics for Engineering Technology }\end{array}$ & D, AT & 1,3 \\
$\begin{array}{l}\text { Students." } \\
\text { *Presentation (P); Group Discussion (D); Simulation (S); Individual Assignment (A1); Team Assignment (AT). }\end{array}$
\end{tabular}

Table 3. Discussion Topics and Exercises Related to Academic Expectations and Skills

\begin{tabular}{lcc}
\hline Discussion Topics \& Exercises & \multicolumn{2}{c}{$\begin{array}{c}\text { Course } \\
\text { Goal }\end{array}$} \\
\hline $\begin{array}{l}\text { Teambuilding \& Communication. Students organize a process into } \\
\text { the most logical order. }\end{array}$ & D, AT & 2,3 \\
\hline $\begin{array}{l}\text { Academic Success Skills. Brainstorm on skills most relevant for } \\
\text { insuring academic success. }\end{array}$ & D & 2,5 \\
\hline $\begin{array}{l}\text { Assessing Learning Styles. Investigate students' own learning style; } \\
\text { discussion to develop a profile of a "typical" engineering technology } \\
\text { student. }\end{array}$ & D, A1 & 2,5 \\
\hline $\begin{array}{l}\text { Developing a Plan For Success. Incorporate information from } \\
\text { Academic Success Skills and Learning Styles exercises to develop } \\
\text { goals and an individualized plan for improvement. }\end{array}$ & A1 & 2,5 \\
\hline $\begin{array}{l}\text { The Final Exam. Students role-play the instructor and discuss how } \\
\text { to develop an assessment to measure each of the course outcomes. }\end{array}$ & D, AT & 2 \\
\hline *Presentation (P); Group Discussion (D); Simulation (S); Individual Assignment (A1); Team Assignment (AT).
\end{tabular}


Table 4. Discussion Topics and Exercises Related to Career Preparation

\begin{tabular}{lcc}
\hline Discussion Topics \& Exercises & \multicolumn{2}{c}{$\begin{array}{c}\text { Course } \\
\text { Goal }\end{array}$} \\
\hline $\begin{array}{l}\text { Developing a Resume. Develop a resume and place it on the } \\
\text { University on-line system. }\end{array}$ & P, A1 & 4 \\
\hline $\begin{array}{l}\text { Alumni Relations. Investigate the University Alumni Career } \\
\text { Network; establish communication with an alum. }\end{array}$ & P, A1 & 4 \\
\hline *Presentation (P); Group Discussion (D); Simulation (S); Individual Assignment (A1); Team Assignment (AT).
\end{tabular}

Table 5. Discussion Topics and Exercises Related to the Engineering Technology Field

\begin{tabular}{|c|c|c|}
\hline Discussion Topics \& Exercises & Format* & $\begin{array}{c}\text { Course } \\
\text { Goal }\end{array}$ \\
\hline $\begin{array}{l}\text { Scavenger Hunt. Locate University and professional resources on } \\
\text { the Web. }\end{array}$ & A1 & 5,6 \\
\hline $\begin{array}{l}\text { Introduction to Mechanical Design (MCT). Investigate field of } \\
\text { study and professional opportunities. }\end{array}$ & $\mathrm{D}$ & 2,5 \\
\hline $\begin{array}{l}\text { Introduction to Industrial Engineering Technology (IET). } \\
\text { Investigate field of study and professional opportunities. }\end{array}$ & $\mathrm{P}, \mathrm{S}, \mathrm{A} 1$ & 5 \\
\hline $\begin{array}{l}\text { Introduction to Electronic \& Computer Engineering Technology } \\
\text { (ECT). Investigate field of study and professional opportunities. }\end{array}$ & $\mathrm{D}$ & 5 \\
\hline $\begin{array}{l}\text { Introduction to Manufacturing Engineering Technology (MFG). } \\
\text { Investigate field of study and professional opportunities. }\end{array}$ & $\mathrm{P}, \mathrm{D}$ & 5 \\
\hline
\end{tabular}

Table 6. Discussion Topics and Exercises Related to University Policies, Procedures, and Culture.

\begin{tabular}{lcc}
\hline $\begin{array}{l}\text { Discussion Topics \& Exercises } \\
\text { The Marianist Community. Presentation on the Marianist charism } \\
\text { and culture at the University. }\end{array}$ & $\begin{array}{c}\text { Course } \\
\text { Goal }\end{array}$ \\
\hline University General Education Requirements. & $\mathrm{P}$ & 6 \\
\hline $\begin{array}{l}\text { Registration Procedures. Discussion on registration procedures and } \\
\text { pitfalls; learn procedures for on-line registration system }\end{array}$ & $\mathrm{P}, \mathrm{D}$ & 6 \\
\hline $\begin{array}{l}\text { Expectations For College. Brainstorm on what to expect from a } \\
\text { college course. }\end{array}$ & $\mathrm{P}, \mathrm{D}$ \\
\hline $\begin{array}{l}\text { Educational Portfolio. Discuss importance of developing an } \\
\text { educational portfolio; develop a portfolio based on information } \\
\text { discussed in FYS course. }\end{array}$ & $\mathrm{D}, \mathrm{A} 1$ \\
\hline \begin{tabular}{l} 
*Presentation (P); Group Discussion (D); Simulation (S); Individual Assignment (A1); Team Assignment (AT). \\
\hline
\end{tabular}
\end{tabular}




\section{Conclusions}

The University of Dayton Department of Engineering Technology is committed to the success of its students. Recent data shows that nearly $85 \%$ of the students who initially enrolled in the School of Engineering remain after one year; considerably higher than the $70 \%$ average for students enrolled in higher education nationally. Moreover, Department of Engineering Technology data shows that over $90 \%$ of the students who passed the FirstYear Seminar were still enrolled in the department one year later, and 50\% of the students who left the department for academic reasons did not perform well in the course.

While no data exists yet to demonstrate a difference in retention between the paperless delivery and the traditional delivery, evaluations from students enrolled in this course in its current delivery mode show a high degree of satisfaction. Overall, they prefer to have information posted electronically and available continuously, rather than relying on handouts and in-class instructions. They also like the flexibility of submitting work electronically, and are comfortable communicating and collaborating electronically with faculty and peers.

The classroom environment is the conduit through which the discovery of knowledge begins. However, it is students' interest and initiative that aids them in investigating the technical field while developing their own educational survival skills. The data suggests that student performance and satisfaction can be increased as educational institutions cater to students' strengths. Computer savvy students use technology to expand their learning environment. Courses that accommodate the technologically adept student will pro vide a conduit for knowledge reaching well beyond the classroom.

\section{References}

1. Kelley, B.S., Burtner, J.A., and Grum, A.F. An Experimental Program To Enhance Retention Of At-Risk Freshmen. 1996 ASEE Annual Conference Proceedings, Washington, DC, 1996.

2. University of Dayton Bulletin 1959-60. Volume 70, Number 2. February, 1959.

3. 2001-2002 Criteria For Accrediting Engineering Technology Programs. Technology Accreditation Commission of the Accreditation Board for Engineering and Technology. [http://www.abet.org].

SCOTT SEGALEWITZ is Associate Professor and Chair of Engineering Technology at the University of Dayton. He earned an MS in Biomedical Engineering from New Jersey Institute of Technology, a BSEE from Rutgers University, and is a licensed Professional Engineer. His areas of interest include distance and asynchronous learning, technical communications, technology in education, and continuous improvement in the learning environment.

Proceedings of the 2002 American Society for Engineering Education Annual Conference \& Exposition Copyright $\odot$ 2002, American Society for Engineering Education 